\title{
A STUDY OF CANDIDA ALBICANS AGGLUTININS IN HUMAN SERA
}

\author{
BY H. I. WINNER \\ Department of Clinical Pathology, Charing Cross Hospital \\ Medical School, London
}

The frequent occurrence of agglutinins to Candida albicans in human sera was first reported by Todd (1937), who tested sera from 1150 presumably normal people, and found agglutinins in $22.5 \%$. Smaller surveys reported by Drake (1945), and by Norris \& Rawson (1947), also disclosed the widespread occurrence of agglutinins. No report has been traced of a similar survey in this country.

Fuentes \& Guarton (1945), in Cuba, found agglutinins in only two sera out of 1002 tested, and considered that the presence of agglutinins usually indicated the presence of clinically important moniliasis. Conant, Smith, Baker, Callaway \& Martin (1954), on the other hand, reported that the presence of agglutinins was inconstant in patients with clinical moniliasis.

The present study consists of a survey of the incidence of agglutinins and an assessment of their clinical significance. Sera of 2017 subjects were screened for the presence of agglutinins by a slide technique. Quantitative agglutinin estimations were performed on the sera of 501 other subjects, 121 of whom were known to be infected with Candida albicans.

\section{MATERIALS AND METHODS}

The stock antigen. A strain of $C$. albicans, supplied by the Mycological Reference Laboratory of the London School of Hygiene and Tropical Medicine, has been maintained for some years on peptone maltose agar, and is frequently tested for pathogenicity and antigenicity in rabbits. Stock suspensions were prepared by washing down fresh overnight subcultures with $0.4 \%$ formol-saline, and standardizing them to a strength of 70 million organisms per ml. by a haemocytometer count. This strength was found to give good visible agglutination by both the slide and the tube method, and the prozone phenomenon was less marked than with weaker suspensions.

The slide-agglutination test. A loopful of the serum under test was mixed on a Perspex slide with a drop of the stock antigenic suspension, so that the final dilution of serum was approximately $1 / 6$. The mixing was continued for about $\frac{1}{2} \mathrm{~min}$., and was followed after $5 \mathrm{~min}$. with a further $\frac{1}{2} \mathrm{~min}$. of mixing. Results were then read.

The quantitative estimation of agglutinins. The antigen used was the stock suspension prepared as above, and also, when available, a suspension of the organism isolated from the particular patient under investigation, similarly prepared and standardized. When both suspensions were used, the results usually agreed closely. 
$0.4 \mathrm{ml}$. volumes of the serum under test in dilutions of $1 / 4,1 / 8$, etc. in normal saline, were prepared in round-bottomed 3 in. $\times \frac{1}{2}$ in. tubes. $0.4 \mathrm{ml}$. of antigen suspension was added to these, and to a control tube of $0.4 \mathrm{ml}$. normal saline. The tubes were covered with metal tube-covers; the rack of tubes was shaken 50 times, and was left in a cupboard at room temperature. Results were usually read the following morning, but they can be read without variation at any time between 6 and $48 \mathrm{hr}$. after the test is set up.

In reading results, each tube was shaken once and examined for agglutination in a curved mirror under a strong light.

\section{RESULTS}

\section{The 'screening' survey}

The sera tested were those received in the laboratory for Wassermann tests during a period of 9 months. 2017 inactivated sera were examined, of which $638(31.6 \%)$ were positive. These totals may be broken down as shown in Table 1.

Table 1

$\begin{array}{lccc}\text { Source of sera } & \text { No. tested } & \text { No. positive } & \begin{array}{c}\text { Percentage } \\ \text { positive }\end{array} \\ \text { Antenatal cases } & \mathbf{1 3 9 1} & 445 & 32 \cdot 0 \\ \text { Other females } & 264 & 94 & \mathbf{3 5 \cdot 6} \\ \text { Males } & \mathbf{3 6 2} & 99 & \mathbf{2 7 \cdot 3}\end{array}$

Comparison of the last two groups reveals a significant difference between the numbers of positives in the two sexes, excluding antenatal cases $(P=0.025)$.

\section{The quantitative survey}

It was evident from the screening survey that the presence of agglutinins to low titre was of little or no clinical significance. The possible association of high titres with Candida infection was then investigated. Estimations were made of the agglutinin titres in consecutive infected cases over a period of about a year and a half. Titres of 1/16 or higher were regarded as of possible clinical significance; such titres are here referred to as high titres.

As latent infection is so widespread, it was impossible to collect a true uninfected control series. Sera of 380 persons in whom infection was not suspected, here called the 'control' group, were examined for comparison with the 'infected' group. Most of these specimens were received in the laboratory for other investigations; the sera of twenty-eight newborn infants and of a smaller number of hospital staff are also included.

These sera were tested in the fresh state, as it had been found that inactivation by heat reduced the titre.

The results obtained are shown in Table 2.

\section{Variation of titre during the course of Candida infection}

Multiple agglutinin estimations were performed in six cases during the course of infection, at intervals ranging from 16 days to 7 months. In no case was a significant rise in titre observed after the passage of time. In two of these cases 
there was a significant fall in titre; in the remainder, no significant variation was observed.

In twenty-four other cases in which only a single estimation was possible, this was performed more than 14 days after the primary isolation of the organism. The titres obtained in this group were as follows: below 16,15 cases; 16,3 cases; 32,3 cases; 64,3 cases; and above 64 , no cases. The distribution of titres in this series thus resembles those in the infected series as a whole.

No evidence was found that the appearance of overt infection is followed by a marked rise in titre, as occurs in bacterial and virus infection.

Table 2. Titres in infected and 'control' sera

\begin{tabular}{|c|c|c|c|c|c|c|c|c|}
\hline & \multicolumn{7}{|c|}{ Titre } & \multirow[b]{2}{*}{ Totals } \\
\hline & $<16$ & 16 & 32 & 64 & 128 & 256 & $>256$ & \\
\hline \multicolumn{9}{|l|}{ Infected series: } \\
\hline Males & 16 & 5 & 1 & 3 & 1 & - & - & 26 \\
\hline $\begin{array}{l}\text { Females (vaginal infections } \\
38 \text {, others } 57 \text { ) }\end{array}$ & 57 & 16 & 12 & 7 & 1 & $\mathbf{l}$ & 1 & 95 \\
\hline Totals & 73 & 21 & 13 & 10 & 2 & 1 & 1 & 121 \\
\hline \multicolumn{9}{|l|}{ Control series: } \\
\hline NIales (excluding neonatals) & 133 & 21 & 5 & 6 & 1 & - & - & 166 \\
\hline Females (excluding neonatals) & 138 & 28 & 17 & 3 & - & - & - & 186 \\
\hline Neonatal cases & 27 & - & 1 & - & - & - & - & 28 \\
\hline Totals & 298 & 49 & 23 & 9 & 1 & - & - & 380 \\
\hline
\end{tabular}

\section{INTERPRETATION OF RESULTS}

(1) A substantial proportion of the population have agglutinins to C. albicans in their serum.

(2) Females have agglutinins more often than males.

(3) Infection is not always associated with a high titre.

(4) A high titre is frequently found in subjects in whom infection is not suspected.

(5) The difference in incidence of high titres between $(a)$ infected males and 'control' males, and between $(b)$ infected females and 'control' females did not reach the conventional levels for statistical significance $(P>0 \cdot 1)$.

(6) There was no significant difference in the incidence of high titres between infected males and infected females.

(7) Females of the 'control' group have high titres more often than males of the same group, but the difference is small $(P \bumpeq 0 \cdot 1)$.

(8) No evidence was obtained that a marked rise in titre occurs during the course of an infection.

\section{DISCUSSION}

It is possible that these agglutinins are normal serum constituents, whose ability to react with $C$. albicans is fortuitous. This view was expressed by Drake (1945), though the material on which he based it, an analysis of the sera of 114 normal 
subjects, was unconvincing. Conclusions (3) and (4) above could be interpreted as supporting this view.

It appears more likely that agglutinins arise as a result of clinical or subclinical infection with $C$. albicans or with antigenically related organisms. Thus, infection occurs more often in females than in males, and females have detectable agglutinins more often than males (Table 1). The fact that infected males and females have a similar incidence of high titres, but that 'control' females have a slightly higher incidence than 'control' males, supports this view.

The difference in the numbers of males and females in a series of 121 consecutive infected cases is of interest. The difference is by no means accounted for by the number of known vaginal infections (Table 2). This suggests that the vagina may often act as a reservoir of latent infection for manifest infection elsewhere.

The frequency with which a high titre occurs in the absence of overt infection, and vice versa, indicates that the detection of a high titre of agglutinins is of little or no diagnostic import in a case of suspected localized or generalized moniliasis. The titre does not appear to rise significantly during the course of infection, possibly because overt infection is preceded by a long period of latent infection.

\section{SUMMARY}

Sera of 2017 subjects were tested by the slide-agglutination method for the presence of agglutinins to Candida albicans. $638(31 \cdot 6 \%)$ were positive, and more females than males had positive sera.

The results are reported of quantitative agglutinin estimations in 501 subjects. 121 of whom were known to be infected with C. albicans.

The significance of $C$. albicans agglutinins is discussed.

I am grateful to my colleagues at Charing Cross and other hospitals, and in general practice, who have allowed me to examine their patients, and who have sent me sera, case histories, and material for culture.

I also acknowledge my indebtedness to Mr Kevin Browne, M.A., who subjected. my results to statistical analysis.

\section{REFERENCES}

Conant, N. F., Smith, D. T., Baker, R. D., Callaway, J. L. \& Martin, D. S. (1954). Manual of Clinical Mycology, 2nd edn., p. 189. Philadelphia and London: W. B. Saunders Co.

Drake, C. H. (1945). J. Immunol. 20, 185.

Fuentes, C. \& Guarton, G. (1945). Rev. méd. cubana, 56, 104.

Norris, R. F. \& Rawson, A. J. (1947). Amer. J. clin. Path. 17, 813.

Todd, R. L. (1937). Amer. J. Hyg. 25, 212.

( $M S$. received for publication 23. VII. 55) 